\title{
IMPROVING MATHEMATIC CONNECTION AND COMMUNICATION CAPABILITY AND SELF-CONCEPT OF VOCATIONAL SCHOOL STUDENTS THROUGH THE SAINTIFIC APPROACH TO THE SETTINGS OF JIGSAW COOPERATIVE LEARNING MODELS
}

\author{
Herry Prasetyo $^{1}$, Euis Eti Rohaeti ${ }^{2}$, Harry Dwi Putra ${ }^{3}$ \\ ${ }^{1}$ STKIP Majenang, Jalan Raya Pahonjean KM.2 Majenang \\ 2, 3 IKIP Siliwangi Bandung, Jalan Terusan Jenderal Sudirman Cimahi \\ ${ }^{1}$ herry19mait@gmail.com, ${ }^{2}$ e2rht@ yahoo.com, ${ }^{3}$ dr.harrydp.mpd@ gmail.com
}

Received: Jul 15 ${ }^{\text {th }}, 2019$; Accepted: Sept $21^{\text {st }}, 2019$

\begin{abstract}
This research was aimed at examining the improving mathematical connection and communication ability and self-concept of vocational students through cooperative learning of jigsaw so that they were able to be more motivated in learning mathematics, more understanding mathematics learning itself and to apply it in everyday life. This research method was a quasi-pretest-posttest experiment that applied a jigsaw cooperative learning model. This study involved two groups of students who studied about mathematical connection and communication skills and students' self-concepts. The instruments used were in the form of mathematical connection and communication skills, as well as student self-concept questionnaires. The research instruments were firstly tested for validity, reliability, distinguishing features and the level of difficulty of the questions. The achievement of mathematical connections and communication skills and the self-concept of students who got learning with a scientific approach to the type of cooperative learning model jigsaw was better than students who only learned the scientific approach. In this study there was also an association between the ability of connections with mathematical communication of students, an association between the ability of connections with students' self-concepts, and an association between mathematical communication skills and students' self-concepts in the high category.
\end{abstract}

Keywords: Mathematical Connection, Mathematical Communication, Student's Self-Concept, Cooperative Jigsaw, Scientific Approach

\begin{abstract}
Abstrak
Penelitian ini akan menelaah tentang meningkatkan kemampuan koneksi dan komunikasi matematik serta konsep diri siswa SMK melaui pembelajaran kooperatif jigsaw sehingga siswa dapat lebih termotivasi dalam belajar matematika, lebih memaknai pembelajaran matematika itu sendiri dan dapat menerapkannya dalam kehidupan sehari-hari. Metode penelitian ini adalah kuasi Experiment pretestposttest yang menerapkan model pembelajaran kooperatif tipe jigsaw. Penelitian ini melibatkan dua kelompok siswa yang diteliti tentang kemampuan koneksi dan komunikasi matematik serta konsep diri siswa. Intrumen yang digunakan berupa soal kemampuan koneksi dan komunikasi matematik, serta angket konsep diri siswa. Instrumen penelitian terlebih dahulu di uji validitas (logis dan empiris), reliabilitas, daya pembeda dan tingkat kesukaran soal. Pencapaian kemampuan koneksi dan komunikasi matematik serta konsep diri siswa yang mendapat pembelajaran dengan pendekatan saintifik model pembelajaran kooperatif tipe jigsaw lebih baik daripada siswa yang mendapat pembelajaran pendekatan saintifik saja. Pada penelitian ini juga terdapat asosiasi antara kemampuan koneksi dengan komunikasi matematik siswa dalam kategori tinggi. Terdapat asosiasi antara kemampuan koneksi dengan konsep diri siswa dalam kategori tinggi. Terdapat asosiasi antara kemampuan komunikasi matematik dengan konsep diri siswa dalam kategori tinggi.
\end{abstract}


Kata Kunci: Koneksi Matematis, Komunikasi Matematis, Konsep Diri Siswa, Kooperatif Jigsaw, Pendekatan Saintifik

How to Cite: Prasetyo, Herry., Rohaeti, Euis Eti., Putra, Harry Dwi. (2019). Improving Mathematic Connection And Communication Capability And Self-Concept Of Vocational School Students Through The Saintific Approach To The Settings Of Jigsaw Cooperative Learning Models. JIML, X (X), XX-XX.

\section{INTRODUCTION}

Mathematics is one branch of science that has an important role in the development of science and technology, both as a tool in the application of other fields of science and in the development of mathematics itself. Mastery of mathematical material by students becomes a necessity that cannot be negotiable in structuring reason and decision making in an era of increasingly competitive competition at this time. But unfortunately, student achievement in mathematics is not very satisfying.

The low results of learning mathematics in Indonesia are caused by several factors. One contributing factor is related to learning held by teachers at schools. Learning at schools tends to be text book oriented and is still dominated by teacher-centered learning and less related to students' daily lives.

Material in mathematics has a relationship between one unit with another unit, therefore a person's ability to connect between units is very necessary in solving mathematical problems. Mathematics subjects are given to students from elementary school, junior high school, senior high school, to college. This certainly has a goal so that students are able to think critically, logically, creatively, and be able to relate the mathematical problems they are dealing with.

Mathematics is a language. Mathematics as a language is certainly very necessary to be communicated both verbally and in writing so that the information conveyed can be known and understood by others [1]. Students need to learn mathematics on the grounds that mathematics is a very powerful, thorough, and not confusing communication tool.

Jigsaw cooperative learning is a learning model that aims to provide a way for students to build intellectual skills (thinking skills) related to reflective thinking processes. If thinking is the main goal of education, then the ways must be found to help individuals to build that ability [2]. In this learning process students are expected to be able to communicate the things they have understood and what they have in mind to build a knowledge they will get.

This research was aimed at examining the improving mathematical connection and communication skills and self-concept of vocational students through cooperative learning jigsaw so that students could be more motivated in learning mathematics, more understanding mathematics learning itself and could apply it in everyday life.

\section{Mathematical Connection}

Mathematical connection ability is the ability of students to associate mathematical concepts both mathematical concepts themselves (in mathematics) and link mathematical concepts with other fields (outside mathematics). Indicators for mathematical connection capabilities are: (a) recognizing and utilizing the relationships between ideas in mathematics; (b) understanding how ideas in mathematics are interrelated and underpin each other to produce a coherent wholeness; (c) recognizing and apply mathematics in contexts outside mathematics. 


\section{Mathematical Communication}

Mathematical communication is an important skill in mathematics [3] namely the ability to express mathematical ideas coherently to friends, teachers, and others through spoken and written languages. The correct use of mathematical language in speaking and writing about what is done, students are able to clarify their ideas and learn to make convincing arguments and present mathematical ideas. Communication [4] is one of the process skills, which is related to the ability of students to convey or receive ideas / ideas to be more creative, both through oral and written.

Indicators of students' mathematical communication skills as follows: (a) connecting real objects, pictures and diagrams into mathematical ideas, (b) explaining mathematical and verbal ideas, situations and reactions with real objects, graphic images and algebra, (c) expressing events everyday in the language or symbol of mathematics, (d) listening, discussing, and writing about mathematics, (e) reading with an understanding of something present in written mathematics.

\section{Concept Of Self}

The concept of self is all the ideas, thoughts, beliefs, and convictions that individuals know about themselves and influence individuals in dealing with others [5]. Indicators of self-concept used in this study are: (1) dimensions of knowledge relating to student participation in mathematics and students' views of their mathematical abilities; (2) expectation dimensions related to the ideal mathematics learning regarding the benefits of mathematics and the active role of students in learning mathematics; (3) assessment dimensions related to how much students like mathematics, namely; students' interest in mathematics and mathematical communication and communication skills.

The scientific approach is a student-oriented approach. In general, it is more effective in increasing the interest and mastery of student concepts both at the tertiary level (students), and at the bottom level (students). The scientific approach is a student-centered learning approach [6]. The findings from [7] show that students who obtain worksheets using a scientific approach have positive opinions on learning.

[8] explains that in this jigsaw learning model students have many opportunities to express opinions, and manage information obtained and can improve communication skills. Group members are responsible for the success of the group and the completeness of the material learned, and can convey to the group.

\section{METHOD}

This research method was a quasi-pretest-posttest experiment that applied a jigsaw cooperative learning model. This study involved two groups of students who were studied about mathematical connection and communication skills and students' self-concepts. The first group used a scientific approach to the Jigsaw cooperative learning model (experimental group) and the second group used a scientific approach only (control group).

The study was carried out at SMK Diponegoro Majenang, located on Jalan Raya Pahonjean, Majenang District, Cilacap Regency, Central Java. The study was conducted in the odd semester of the 2019/2020 school year during August 2019. 
The instruments used were in the form of mathematical connection and communication skills, as well as student self-concept questionnaires. The research instruments were firstly tested for validity (logical and empirical), reliability, distinguishing features and the level of difficulty of the questions.

The data analysis technique used were to process the results of the pretest, posttest, self-concept questionnaire, student activity sheet, teacher activity sheet and the results of the interview. All data in this study were processed and analyzed through multivariate tests (MANOVA) using the IBM SPSS Statistics 21 software program. The conclusions in this study were seen from the MANOVA test with a value of $\mathrm{H}_{0}$ (rejected or accepted).

The scientific approach with the setting of a jigsaw cooperative learning model was an independent variable, while connections and communication as well as mathematical selfconcepts were dependent variables. The prerequisite test was performed before analyzing the MANOVA test, the nine prerequisite test steps were described as follows [9] (Stevens, 2002): (1) Dependent variable consisted of two or more and in the form of continuous data; (2) Independent variable consisted of two or more categories; (3) Observation of each class was different from the previous trial class; (4) Sufficient sample with the number of students was > 25 for each class; (5) There were no univariate and multivariate outliers; (6) Multivariate Normality Test; (7) Linearity test between each independent variable pairs for each dependent variable group; (8) Homogeneity test of variance-covariance matrices; (9) Correlation Test (No multicollinearity).

\section{RESULTS AND DISCUSSION}

\section{Results}

Jigsaw type cooperative learning models involved students actively through the process of thinking of the material presented in the exercise, then students communicated the results of their thoughts on the material both in student work groups or presenting it in front of the class. Students could take notes in the form of summaries of material that had been learned after going through the process of thinking and communicating. Figure 1 shows that students are being given apperception and self-concept attitudes by the teacher and pay attention to the direction of the teacher.

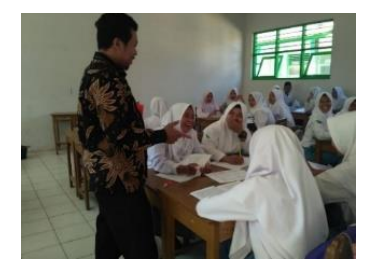

Figure 1. The Teacher Gives Apperception and Self Concept

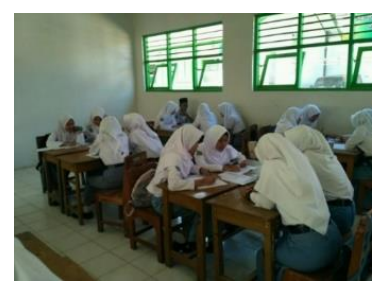

Figure 2. Student Discussion

Figure 2 shows that students are discussing and communicating in a group. The results of research and findings related to the development of connection and communication skills and 
mathematical self-concept of students in a group of students who were given treatment in the form of learning with a scientific approach to the type of cooperative learning model jigsaw and with a scientific approach to conventional learning models.

Table 1. Result of Pretest, Posttest, Student N-gain in Experiment and Control Classes

\begin{tabular}{|c|c|c|c|c|c|c|c|}
\hline $\begin{array}{c}\text { Dependent } \\
\text { Variable }\end{array}$ & Statistic & \multicolumn{3}{|c|}{$\begin{array}{l}\text { Scientific Approach To } \\
\text { The Type Of Cooperative } \\
\text { Learning Model Jigsaw } \\
(\mathrm{n}=32)\end{array}$} & \multicolumn{3}{|c|}{$\begin{array}{c}\text { Scientific Approach To } \\
\text { Conventional Learning } \\
\text { Model } \\
(\mathbf{n}=32)\end{array}$} \\
\hline $\begin{array}{l}\text { Mathematical } \\
\text { Connection }\end{array}$ & $\begin{array}{l}\bar{x} \\
\%\end{array}$ & $\begin{array}{c}\text { Pretest } \\
22,83 \\
22,83\end{array}$ & $\begin{array}{c}\text { Posttest } \\
75,67 \\
75,67\end{array}$ & $\begin{array}{c}N \text {-gain } \\
0,69 \\
\text { (medium) }\end{array}$ & $\begin{array}{c}\text { Pretest } \\
31,17 \\
31,17\end{array}$ & $\begin{array}{c}\text { Posttest } \\
75,5 \\
75,5\end{array}$ & $\begin{array}{c}\boldsymbol{N} \text {-gain } \\
0,64 \\
\text { (medium) }\end{array}$ \\
\hline $\begin{array}{l}\text { Mathematical } \\
\text { Communication }\end{array}$ & $\begin{array}{l}\bar{x} \\
\%\end{array}$ & $\begin{array}{l}20,83 \\
20,83\end{array}$ & $\begin{array}{l}85,5 \\
85,5\end{array}$ & $\begin{array}{c}0,82 \\
\text { (high) }\end{array}$ & $\begin{array}{l}19,5 \\
19,5\end{array}$ & $\begin{array}{l}74,0 \\
74,0\end{array}$ & $\begin{array}{c}0,67 \\
\text { (medium) }\end{array}$ \\
\hline
\end{tabular}

The average $\mathrm{N}$-gain posttest score against the mathematical connection pretest score obtained results in an increase in the mathematical connection ability of the experimental class students better than the control class students even though the increase for both classes was moderate, namely 0.69 and 0.64 .

Table 2. Result of Student Self Concept Score in Experiment and Control Classes

\begin{tabular}{ccc}
\hline \multirow{2}{*}{ Variable } & \multicolumn{2}{c}{ Self-Concept } \\
\cline { 2 - 3 } & Experiment & Control \\
\hline Score & 4,57 & 3,21 \\
Category & Very Good & Average \\
\hline
\end{tabular}

The students' self-concept data of the scientific approach class of jigsaw cooperative learning model was 4.57 with very good category and the class with scientific approach of 3.21 was good enough based on the calculation of standard scores 1-5. This shows that the selfconcept of the experimental class students was better than the control class.

The results obtained from the calculation were descriptively strengthened by carrying out statistical testing that was by using the MANOVA test. The nine prerequisite test steps were carried out coherently and produced data such as the following:

a. The dependent variable consisted of two namely mathematical communication and communication capabilities as well as mathematical self-concepts in the form of continuous data.

b. The independent variable consisted of the two categories namely the jigsaw type cooperative learning model tested in the experimental class and the scientific approach to the conventional learning model applied in the control class.

c. The observations of each class (empirical trials, limited trials, and extensive tests) differed from the pilot classes previously

d. Sufficient sample with 32 students for control and experimental classes;

e. There were no univariate and multivariate outliers which can be seen from figure 3 (a) and (b) that show that there were no univariate outliers on the results of mathematical communication and communication ability data analysis results, because in the bloxplot result there was no small circle around the block, 


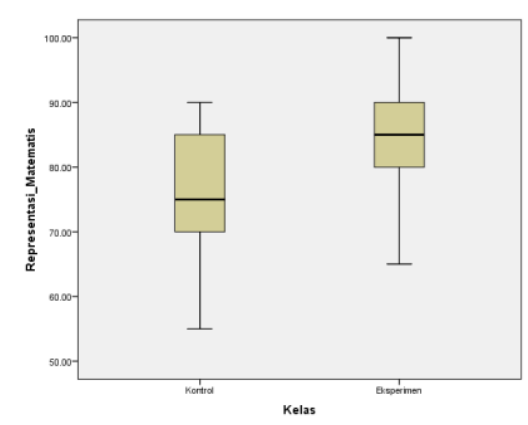

(a)

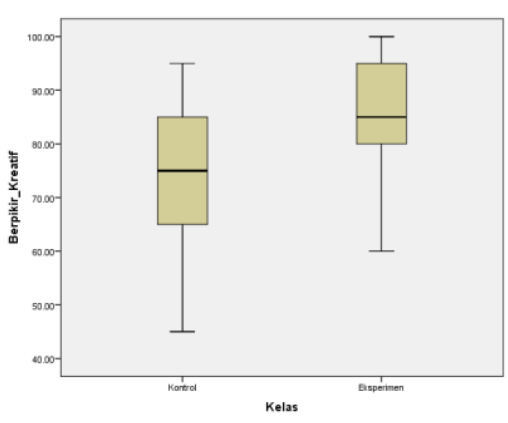

(b)

Figure 3.Univariat Outliers Mathematical Connection Ability (a) Mathematical Communication Ability (b)

then figure 4 (a) and (b) that show that there were no multivariate outliers in the results of multivariate data analysis seen from Mahalanobis Distance with Chi Square in the second class class.



(a)

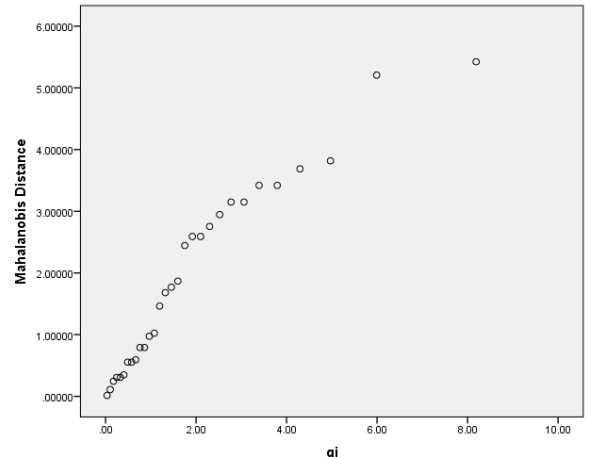

(b)

Figure 4. Multivariat Outliers between Mahalanobis Distance with Chi Square on experiment class (a) and control class (b)

f. Multivariate Normality Test, normality analysis on the Shapiro-Wilk test obtained sig. more than 0.05 so that it was concluded that $\mathrm{H}_{0}$ was accepted. This means that the data of the two experimental and control class groups were normally distributed.

g. Linearity test between each pair of independent variables for each group of dependent variables. Data were normally distributed multivariate if scatter-plots tended to gather together and did not spread too broadly.

h. Homogeneity test of variance-covariance matrices, Table 5 shows the sig. mathematical connection and communication skills of 0.059>0.05, the mathematical connection and communication capability values had relatively similar variances.

Table 5. Result of Homogenity Test

\begin{tabular}{lr}
\hline \multicolumn{2}{c}{ Box's Test of Equality of Covariance Matrices } \\
Box's M & 11.926 \\
F & 3.836 \\
df1 & 3 \\
df 2 & 691920.000 \\
Sig. & .059 \\
\hline
\end{tabular}

i. Correlation Test (No multicollinearity), Table 6 shows that the Pearson Correlation results obtained value $\mathrm{r}=0.332$ included in the category so weak that $\mathrm{H}_{0}$ was rejected and $\mathrm{Ha}$ was 
accepted. The conclusion is that there was a correlation between the ability of connection and mathematical communication in the experimental class and the control class.

Table 6. Result of Bivariat Pearson Correlation Test

\begin{tabular}{llrr}
\hline & \multicolumn{2}{c}{ Correlations } \\
\hline & \multicolumn{1}{c}{$\begin{array}{c}\text { Conection_ } \\
\text { mathematical }\end{array}$} & $\begin{array}{c}\text { Communication_ } \\
\text { mathematical }\end{array}$ \\
\hline $\begin{array}{l}\text { Conection } \\
\text { mathematical }\end{array}$ & Pearson Correlation & 1 & $.332^{* *}$ \\
\cline { 2 - 5 } & Sig. (2-tailed) & 64 & .008 \\
\cline { 2 - 5 } $\begin{array}{l}\text { Communication } \\
\text { mathematical }\end{array}$ & $\mathrm{N}$ & $.332^{* *}$ & 64 \\
\cline { 2 - 5 } & Pearson Correlation & .008 & 64 \\
\cline { 2 - 5 } & $\mathrm{N}$ & 64 & 6 \\
\hline
\end{tabular}

The association between mathematical connections and communication as well as students' self-concepts used contingency associations. The thing that must have been done first before doing contingency statistical calculations was that the data already obtained was changed first into nominal data. According [10], contingency coefficient is used to calculate the relationship between variables if the data is nominal. Qualification criteria are determined for the benefit of the data set.

Table 8. Results of Connection Contingency Test and Mathematical Communication

\begin{tabular}{lllr}
\hline & & Value & Approx. Sig. \\
\hline Nominal by Nominal & Contingency Coefficient & .598 & .001 \\
N of Valid Cases & & 32 & \\
\hline
\end{tabular}

Table 8 shows the contingency coefficient $\mathrm{C}=0.598$. In order for $\mathrm{C}$ prices to be used to assess the degree of association between the two variables, $\mathrm{C}$ prices needed to be compared with $\mathrm{Cmax}$ prices. The resulting Cmax value was 0.732. It was concluded that the degree of contingency association between the ability of connections with students' mathematical communication was relatively high.

Table 9. Results of Self Concept Contingency Test and Mathematical Connection

\begin{tabular}{lllr}
\hline & & \multicolumn{1}{c}{ Value } & Approx. Sig. \\
\hline Nominal by Nominal & Contingency Coefficient & .450 & .002 \\
N of Valid Cases & & 32 & \\
\hline
\end{tabular}

Table 9 shows the value of the contingency coefficient $\mathrm{C}=0.450$. The $\mathrm{C}$ price could be used to assess the degree of association between the two variables, so the $\mathrm{C}$ price needed to be compared with the Cmax price. The resulting Cmax value was 0.551. It was concluded that the degree of contingency association between the ability of connections with students' self-concept was quite high.

Table 10. Results of Hasil Self Concept Contingency Test and Mathematical Communication

\begin{tabular}{lcc}
\hline & Value & Approx. Sig. \\
\hline Nominal by Nominal Contingency Coefficient & .583 & .001 \\
N of Valid Cases & 32 & \\
\hline
\end{tabular}

Table 10 shows the contingency coefficient $\mathrm{C}=0.583$. The $\mathrm{C}$ price could be used to assess the degree of association between the two variables, then the $\mathrm{C}$ price needed to be compared with 
the Cmax price. The Cmax price generated value was 0.714 . It was concluded that the degree of contingency association between mathematical communication skills and students' selfconcepts was high.

\section{Discussion}

This study used two types of learning, namely the scientific approach of the Jigsaw cooperative learning model for the experimental class and learning by learning the scientific approach only for the control class with the aim to examine the improvement of mathematical connection and communication skills as well as students' self-concepts in both classes.

The average $\mathrm{N}$-gain posttest score against the mathematical connection pretest score obtained results in an increase in the mathematical connection ability of the experimental class students better than the control class students even though the increase for both classes was moderate, namely 0.69 and 0.64 . Increasing the mathematical connection ability of the experimental class students was better than the control class. The ability of mathematical connections can applied mathematics in other fields or in everyday life, to understand the equivalent representation of a mathematical concept or procedure, to seek the relationship of various representations of concepts, processes, or mathematical procedures, procedures with other procedures in the equivalent representation [11]. One of the different mathematical connection abilities is one of them because the subject has a different understanding of the concepts used to solve problems [12].

The $\mathrm{N}$-gain score of the posttest score against the pretest score of mathematical communication skills obtained results that the increase in mathematical communication skills of the experimental class students was better than the control class students with the experimental class having a high category and a control category of moderate category namely 0.82 and 0.67 . Improved mathematical communication skills of the experimental class students was better than the control class. Students who have good analogy skills also have good communication skills. A strong relationship between these abilities suggests that the analogy and communication skills are very important for students in solving math problems [7].

The percentage of observation sheets of science process skills on communication ability is categorized as good for all students on learning procces [13]. Students have excellent mathematical communication skills in analyzing problems to be able to solve with good communication skills [14]. [15] found that the grade of mathematical communication ability of students taught by PBL was classified as fairly good and it was better than the grade of students taught by conventional teaching.

Based on the description and results of the statistical tests of mathematical connection and communication skills above, it illustrates that the Jigsaw type cooperative learning model was better and contributed better in developing students' mathematical communication skills.

Statistical test results on the questionnaire score, based on the results of the analysis it was found that the results of self-concept in the experimental and control classes respectively 4.57 and 3.21 were categorized very good and quite good. It could be concluded that there was a difference between students' self-concepts who got a scientific approach to the type of Jigsaw cooperative learning model and students who only learned scientific approaches. This fact shows that the increase in self-concept of the experimental class students was better than the control class students. This was because the scientific approach of the Jigsaw cooperative learning model could improve students' activities and self-concepts in the classroom. The same 
study was also conducted by [16] which resulted that there was a significant influence on students 'self-concepts in mathematics and student learning independence together on mathematics learning achievement and there was a significant effect of students' self-concepts in mathematics on learning achievement mathematics.

Based on the association between variables in table 8 , it was obtained the value of Sig. which was $0.001<0.05$ indicating $\mathrm{H} 0$ was rejected, meaning that there was a significant association between the ability of mathematical connections and student self-concept. The value of contingency coefficient $C$ was 0.598 and $Q=0.732$ so it could be concluded that the degree of association between students' mathematical communication and communication skills was high. Table 9 obtained the value of Sig. which was $0.021<0.05$ indicating that $\mathrm{H} 0$ was rejected, meaning that there was a significant association between self-concept and students' mathematical connection abilities. The degree of association between self-concept and mathematical connection ability was quite high. Table 10 obtained the Sig. which was 0.001 $<0.05$ indicating $\mathrm{H}_{0}$ was rejected, meaning that there was a significant association between the ability of self-concept and students' mathematical communication. The value of contingency coefficient $\mathrm{C}$ was 0.583 and $\mathrm{Q}=0.714$ so it could be concluded that the degree of association between students' self-concepts and mathematical communication was high.

The average posttest results of the experimental class and control class students were moderate. The average test of students' mathematical connections and communication skills was not much different. This meant that mathematical connection and communication ability test questions had the same level of difficulty. Most students in the control class cannot solved the problem better than the experimental class.

\section{CONCLUSION}

Based on data analysis and research findings obtained in the field during the research, conclusions can be obtained, namely: achievement of mathematical communication and connection abilities and self-concept of students who get learning with a scientific approach to the type of cooperative learning model jigsaw was better than students who received learning only scientific approaches.

In this study there was also an association between the ability of connections with mathematical communication of students in the high category. There was an association between the ability of connections with students' self-concepts in the high category. There was an association between mathematical communication skills and students' self-concepts in the high category.

\section{REFERENCES}

[1] E. Suherman. (2003). Strategi Pembelajaran Matematika Kontemporer. Bandung: JICA. [2] Wahyudin. (2008). Pembelajaran dan Model-model Pembelajaran. Bandung: UPI.

[3] K. N. Harahap and E. Surya, "Kemampuan komunikasi matematika siswa dalam pembelajaran matematika," no. December, 2017.

[4] N.S. Agisti. (2009). Implementasi Strategi Means - Ends Analysis Untuk Meningkatkan Kemampuan Siswa SMP Dalam Komunikasi Matematik.

[5] E. Saputra. (2012). Pengaruh Penggunaan Model Pembelajaran Anchored Intruction Terhadap Peningkatan Kemampuan Komunikasi Matematik dan Konsep diri Siswa. Disertasi Upi Bandung. Tidak Diterbitkan

[6] A. Saregar, "Pembelajaran pengantar fisika kuantum dengan memanfaatkan media phet simulation dan $1 \mathrm{~km}$ melalui pendekatan saintifik: dampak pada minat dan penguasaan 
konsep mahasiswa," J. Ilm. Pendidik. Fis. Al-BiRuNi, vol. 05, no. 1, pp. 53-60, 2016.

[7] H. Hendriana, H. D. Putra, and M. G. Ristiana, "Scientific approach in developing mathematical analogy and communication ability of junior high school students in remote areas," Int. Conf. Math. Sci. Educ., vol. 3, no. 103, pp. 597-601, 2018.

[8] Rusman. 2008. Model Pembelajaran Kooperatif Jigsaw.

[9] J. Steven. (2002). Applied multivariate statistics for the social sciences. London: Lawrence erlbaum associates.

[10] Sugiyono. 2011. Metode Penelitian Kuantitatif, Kualitatif dan R\&D. Bandung: Afabeta.

[11] D. N. Adni, P. Nurfauziah, and E. E. Rohaeti, "Analisis kemampuan koneksi matematis siswa SMP ditinjau dari self efficacy siswa," J. Pembelajaran Mat. Inov., vol. 1, no. 5, pp. 957-964, 2018.

[12] R. S. Lestari, E. E. Rohaeti, and R. Purwasih, "Profil kemampuan koneksi matematis siswa SMP dalam menyelesaikan soal bangun ruang sisi datar ditinjau dari kemampuan dasar," J. Ilm. Pendidik. Mat., vol. 3, no. 1, pp. 51-58, 2018.

[13] F. P. Sari, L. Ratnaningtyas, I. Wilujeng, Jumadi, and H. Kuswanto, "Development of android comics media on Thermodynamic experiment to map the science process skill for Senior High School," IOP Conf. Ser. J. Phys. Conf. Ser. 1233, no. 012052, pp. 1-9, 2019.

[14] S. Robiah, E. E. Rohaeti, and E. Senjayawati, "Analisis kemampuan komunikasi matematika siswa berdasarkan minat belajar matematis siswa SMK Negeri 1 Cihampelas," J. Educ., vol. 01, no. 02, pp. 365-371, 2019.

[15] H. Hendriana, U. Sumarmo, and E. E. Rohaeti, "Kemampuan komunikasi matematik serta kemampuan dan disposisi berpikir kritis matematik," Delta-Pi J. Mat. dan Pendidik. Mat., vol. 2, no. 1, pp. 35-45, 2013.

[16] Y. Purnomo, "Pengaruh sikap siswa pada pelajaran matematika dan kemandirian belajar siswa terhadap prestasi belajar matematika," JKPM, vol. 02, no. 01, pp. 93-105, 2016. 